\title{
Prevalence and risk factors of internet gaming disorder and problematic internet use before and during the COVID-19 pandemic: A large online survey of Japanese adults
}

Taiki Oka ${ }^{1 \dagger}$, Toshitaka Hamamura ${ }^{2 \dagger}$, Yuka Miyake ${ }^{3}$, Nao Kobayashi $^{3}$, Masaru Honjo², Mitsuo Kawato ${ }^{1}$, Takatomi Kubo ${ }^{4}$, Toshinori Chiba ${ }^{1,5,6}$

1The Department of Decoded Neurofeedback, Computational Neuroscience Laboratories, Advanced Telecommunications Research Institute International, Kyoto, Japan

2Health-improving Behavior Change Laboratory, Innovation Center, KDDI Research, Inc., Saitama, Japan

3Technology Strategy Department, Technology Planning Division, KDDI CORPORATION, Tokyo, Japan

4The Department of Brain robot interface, Computational Neuroscience Laboratories, Advanced Telecommunications Research Institute International, Kyoto, Japan

5The Department of Psychiatry, Self-Defense Forces Hanshin Hospital, Kawanishi, Japan 6The Department of Psychiatry, Kobe University Graduate School of Medicine, Kobe, Japan †These authors contributed equally as co-first authors.

*Send correspondence to Toshinori Chiba, t.chiba0906@gmail.com

Advanced Telecommunications Research Institute International, 2-2-2 Hikaridai Seika-Cho, Soraku-gun, Kyoto 619-0288 JAPAN

TEL: +81-774-95-1111 
FAX: +81-774-95-1236

Ethics

Prospective participants received information by Email about informed consent. Completion of the questionnaire was considered to indicate a participant's consent. This study is a part of a larger study on problematic smartphone use, which was approved by the Ethics Committee of the Advanced Telecommunications Research Institute International (Japan).

\section{Funding}

This research was supported by a KDDI collaborative research contract. It was also supported by Innovative Science and Technology Initiative for Security Grant Number JPJ004596, ATLA, Japan.

\section{Data availability}

Statistical data that support findings of this study are available in Supplementary Data. Owing to company cohort data sharing restrictions, individual-level data cannot be publicly posted. Data are, however, available from the authors upon reasonable request and with permission of KDDI Corporation.

\section{Author Contributions}

TO, TH and TC made substantial contributions to the study conception and design. TO, TH, NK, YM, MH, and TC contributed significantly to data acquisition. TO, NK, TK, and TC conducted statistical analyses. TO, MK, and TC made substantial contributions to interpretation of data. TO drafted the first version of the manuscript. All authors contributed to critical revisions and approved the final version of the manuscript. TC assumes responsibility for the integrity of the work. 
medRxiv preprint doi: https://doi.org/10.1101/2021.03.30.21254614; this version posted March 31, 2021. The copyright holder for this preprint (which was not certified by peer review) is the author/funder, who has granted medRxiv a license to display the preprint in perpetuity.

It is made available under a CC-BY-NC-ND 4.0 International license .

\section{Abstract}

Internet gaming disorder (IGD) and problematic internet use (PIU) are becoming increasingly detrimental in modern society, with serious consequences for daily functioning. IGD and PIU may be exacerbated by lifestyle changes imposed by the coronavirus 2019 (COVID-19) pandemic. This study investigated changes in IGD and PIU during the pandemic and risk factors for them. This study is a part of a larger online study on problematic smartphone use in Japan, originally planned in 2019, and expanded in August 2020 to include the impact of COVID-19. 51,246 adults completed an online survey during the pandemic (August 2020), in Japan. Of these, 3,938 had also completed the survey before the onset of the pandemic (December, 2019) and were used as the study population to determine how the pandemic has influenced IGD and PIU. IGD was assessed using the Internet Gaming Disorder Scale (IGDS). PIU was measured using the Compulsive Internet Use Scale (CIUS). The prevalence of probable IGD during COVID-19 was $4.1 \%$ [95\% $\mathrm{Cl}, 3.9 \%$ to $4.2 \%$ ] overall $(\mathrm{N}=51,246)$, and $8.6 \%$ among younger people $($ age $<30)$, higher than reported before the pandemic $(1-2.5 \%)$. Probable PIU was $7.8 \%$ [ $95 \% \mathrm{Cl}, 7.6 \%$ to $8.1 \%]$ overall, and $17.0 \%$ [95\%Cl, $15.9 \%$ to $18.2 \%]$ among younger people, also higher than reported before the pandemic (3.2 - 3.7\%). Comparisons before and during the pandemic, revealed that probable IGD prevalence has increased 1.6 times, and probable PIU prevalence by 1.5 times (IGD: $t_{3937}=5.93, p<.001$, PIU: $t_{3937}=6.95, p<.001$ ). Youth (age < 30) and COVID-19 infection were strongly associated with IGD exacerbation (odds ratio, $2.10[95 \% \mathrm{Cl}, 1.18$ to 3.75$]$ and $5.67[95 \% \mathrm{Cl}, 1.33$ to 24.16$])$. Internet gaming disorder and problematic internet use appear to be aggravated by the pandemic. In particular, younger persons and people infected with COVID-19 are at higher risk for Internet Gaming Disorder. Prevention of these problems is needed.

Keywords: internet gaming disorder; problematic internet use; COVID-19; risk factor; large online study; prevention 
medRxiv preprint doi: https://doi.org/10.1101/2021.03.30.21254614; this version posted March 31, 2021. The copyright holder for this preprint (which was not certified by peer review) is the author/funder, who has granted medRxiv a license to display the preprint in perpetuity.

It is made available under a CC-BY-NC-ND 4.0 International license .

\section{Introduction}

The coronavirus 2019 (COVID-19) pandemic has affected all aspects of society (Holmes et al., 2020; McGinty et al., 2020). Previous studies have suggested that stressors due to the pandemic contribute to increased addictive behaviors, such as substance use, alcohol, food, and social media (Bonny-Noach and Gold, 2020; Panno et al., 2020). The World Health Organization (WHO) has warned that during the COVID-19 pandemic, screen time and gameplaying time may increase. This increases the risk of Internet and gaming addiction(WHO, 2020). Increased video gameplay and internet use among young people have been reported(Schmidt et al., 2020), possibly because of pandemic-induced lifestyle changes (e.g., staying at home, quarantines, closed workplaces, and schools (King et al., 2020; WHO, 2020)). While video games and the internet provide entertainment and convenience, maladaptive engagement in these activities can lead to various mental health problems, including internet gaming disorder (IGD) and problematic internet use (PIU). IGD and PIU are associated with greater psychological distress, poorer sleep quality, and severe social withdrawal, known as 'hikikomori' (Kato et al., 2020; Wong et al., 2020; Fazeli et al., 2020). Several opinion papers have cautioned that increased severity of IGD and IPU during a pandemic could persist after its subsidence, which may prolong poor quality of life for those affected and may impose a heavy economic burden on society (King et al., 2020; Ko and Yen, 2020). Young people have an especially great risk of internet-related problems and psychological distress during the pandemic (Chen et al., 2021, 2020; Fazeli et al., 2020; Sun et al., 2020). Such epidemiological studies are important in formulating policies for prevention and early intervention. However, to the best of our knowledge, most previous studies have been employed a cross-sectional approach. One study, which included only adolescents, found increased rates of internet-related problem behaviors in March 2020, compared with November 2019 (Chen et al., 2021). Therefore, changing IGD and PIU levels among adults before and during the pandemic remain unclear. Using online survey data from 51,246 adults, we investigated the prevalence of IGD 
medRxiv preprint doi: https://doi.org/10.1101/2021.03.30.21254614; this version posted March 31, 2021. The copyright holder for this preprint (which was not certified by peer review) is the author/funder, who has granted medRxiv a license to display the preprint in perpetuity.

It is made available under a CC-BY-NC-ND 4.0 International license .

and PIU. The influence of the COVID-19 pandemic on IGD and PIU was assessed by comparing online survey data from a subsample of 3,938 adults collected before and during the pandemic.

\section{Material and methods}

\section{Participants and Procedures}

This investigation was a part of a larger study on the association between problematic smartphone use and multidimensional psychiatric states that was initiated in 2019 and later expanded to examine the impact of COVID-19 (Figure 1). Details can be found in our previous work(Chiba et al., 2020). It was approved by the Ethics Committee of the Advanced Telecommunications Research Institute International (Japan).

5,955 participants, screened in December 2019, immediately before COVID-19, reported their multi-dimensional psychiatric states, including IGD and CIUS (Figure 1). In order to assess changes in multiple psychiatric states during the pandemic, we conducted a follow-up survey in July 2020 that contained additional questions related to COVID-19 (e.g., Do you think that you have ever been infected by COVID-19?). 52,737 people responded to the July, 2020 survey, including 5,793 who participated in December, 2019 (Figure 1). Of the latter, 1,445 participants dropped out and 198 participants were excluded because of inconsistencies in their answers. An additional 212 participants were deleted because they responded identically to all items using only the maximum or minimum values. In the end, 3,938 respondents were included in the current analyses (Figure 1). 
medRxiv preprint doi: https://doi.org/10.1101/2021.03.30.21254614; this version posted March 31, 2021. The copyright holder for this preprint (which was not certified by peer review) is the author/funder, who has granted medRxiv a license to display the preprint in perpetuity.

It is made available under a CC-BY-NC-ND 4.0 International license .

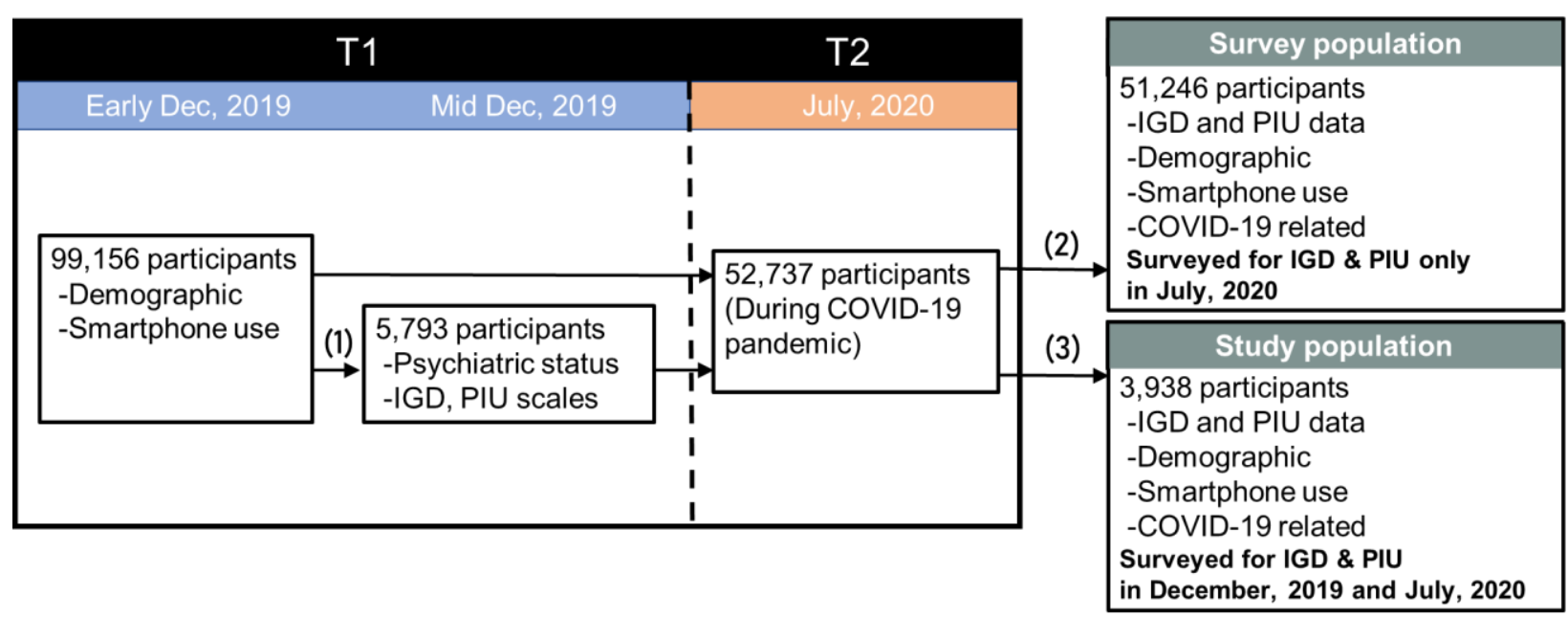

Figure 1. Flow chart showing numbers of participants and criteria for exclusion from the analyses.

(1) This subpopulation includes equal numbers of individuals in each quintile relative to their problematic smartphone use score. These 5,793 respondents were drawn from the larger sample of 99,156 participants. (2) 52,737 participants from the early December, 2019 survey participated in a July, 2020 survey that included IGD/PIU and COVID-19 questions that were not in the original December, 2019 survey. 1,491 of the 52,737 participants were excluded because of inconsistencies in their answers. (e.g. sleep time $=$ wake-up time, 1 st gender $\neq 2$ nd gender). (3) 5,793 respondents from late December, 2019, who were asked questions about IGD/PIU, participated in the July, 2020 follow-up survey, in which they were also asked questions about COVID-19. 1,855 participants had to be excluded because they dropped out of the survey, there were inconsistencies in their answers, or because they responded identically to all items, using only the maximal or minimal values. This left 3,938 people who participated in both the late December, 2019 and July, 2020 surveys. 
medRxiv preprint doi: https://doi.org/10.1101/2021.03.30.21254614; this version posted March 31, 2021. The copyright holder for this preprint (which was not certified by peer review) is the author/funder, who has granted medRxiv a license to display the preprint in perpetuity.

It is made available under a CC-BY-NC-ND 4.0 International license .

\section{Measures}

IGD was measured according to the Japanese-version Internet Gaming Disorder Scale (IGDS), which consists of questions corresponding to each of the nine IGD symptoms defined in the Diagnostic and Statistical Manual of Mental Disorders, 5th ed (DSM-5)(American Psychiatric Association, 2013). Using a binary response format, items assessed the severity of each IGD symptom during the preceding 12 months. At least five symptoms are required to return a diagnosis of IGD. The reliability and validity of IGDS have been demonstrated with a Cronbach's alpha of 0.93 (Lemmens et al., 2015). PIU was measured using the Compulsive Internet Use Scale (CIUS), which has a Cronbach's alpha of 0.89 . Construct validity has been confirmed by the strong positive correlation with the Online Cognition Scale $(r=0.70, p<.001)$ and the amount of time spent online $(r=0.33, p<.001)$ (Meerkerk et al., 2009). We defined probable

IGD as a total IGDS $\geq 5$, and probable PIU as a total CIUS score of $\geq 29$ (Jeromin et al., 2016).

\section{Statistical analysis}

Average IGDS and CIUS scores and the prevalence of probable IGD and PIU based on these scales were calculated for each age and sex group for both T1 (December, 2019, before COVID-19) and T2 (July, 2020, during COVID-19) ( $\mathrm{N}=3,938)$. Changes in prevalence of probable IGD and probable PIU were analyzed using paired t-tests. We also analyzed each IGD item similarly. Bonferroni correction was used to adjust the multiple comparisons for analysis of each IGD item. Further, to explore the effects of demographic characteristics and infections of COVID-19 on IGD and PIU status, we conducted multiple logistic regression analyses to predict who developed probable IGD and probable PIU during the period between T1 and T2. To do so, participants without probable IGD or PIU at T1 were excluded for each analysis, separately. Demographic characteristics included sex, marital status, the existence of children, age groups, 
medRxiv preprint doi: https://doi.org/10.1101/2021.03.30.21254614; this version posted March 31, 2021. The copyright holder for this preprint (which was not certified by peer review) is the author/funder, who has granted medRxiv a license to display the preprint in perpetuity.

It is made available under a CC-BY-NC-ND 4.0 International license .

household income, COVID-19 infection status, changes in the amount of communication with family from T1 to T2 (face-to-face and online, separately), and changes in smartphone use time from T1 to T2 (weekdays and weekends, separately).

Model specification:

logit $(I G D$ or PIU) = Intercept + sex + marital status + the existence of children + age groups + household income + the status of COVID-19 infection + changes in the amount of face-to-face communication with family from $T 1$ to $T 2+$ changes in the amount of online communication with family from $T 1$ to $T 2$ + change in smartphone use time from T1 to T2 on weekdays + change in smartphone use time from T1 to T2 on weekends

* IGD and PIU denote the state of probable IGD or probable PIU at T2, respectively

All demographic characteristics were treated as categorical variables. The odds ratio of each group for a given variable was calculated against the reference group. Reference groups were decided according to previous studies (Shen et al., 2020; Tsumura et al., 2018). To test potential selection bias, Pearson correlation analysis was performed for the prevalence of probable IGD and probable PIU in each age and sex group between the survey population and the study population. Statistical analyses were performed using Matlab version R2019b.

Statistical tests assumed a significance level $\alpha$ of $5 \%$, except for the analysis of the difference of IGD items from T1 to T2, for which Bonferroni correction was used.

\section{Results}

\section{Sample characteristics}

The average age of participants was 46.6 years [standard deviation $(\mathrm{SD})=11.8$ ], and $49.9 \%$ were male (Table 1$)$. The prevalence of probable IGD was $4.1 \%(95 \% \mathrm{Cl}$ [3.9\% to $4.2 \%])$ and that of PIU was $7.8 \%(95 \% \mathrm{Cl}[7.6 \%$ to $8.0 \%])$. The probable prevalence of IGD among 
medRxiv preprint doi: https://doi.org/10.1101/2021.03.30.21254614; this version posted March 31, 2021. The copyright holder for this preprint (which was not certified by peer review) is the author/funder, who has granted medRxiv a license to display the preprint in perpetuity.

It is made available under a CC-BY-NC-ND 4.0 International license .

young people $(<30$ age) was $8.6 \%(95 \% \mathrm{Cl}[7.8 \%$ to $9.5 \%])$ and that of $\mathrm{PIU}$ was $17.0 \%(95 \% \mathrm{Cl}$ [15.9\% to $18.2 \%]$ ). Among adults, prevalence of probable IGD increased 1.5 times during the pandemic $\left(t_{3937}=5.93, p<.001\right)$ and PIU increased 1.6 times $\left(t_{3937}=6.95, p<.001\right)$. In young people, IGD prevalence increased 1.8 times during the pandemic $\left(t_{310}=3.36, p<.001\right)$ and PIU prevalence increased 1.6 times $\left(t_{310}=3.30, p=.001\right)$.

Table 1. Demographic characteristics in the survey population of the COVID-19 online survey.

\begin{tabular}{|c|c|c|c|c|c|c|c|c|}
\hline & & $\begin{array}{l}\text { Sample } \\
\text { size }\end{array}$ & $\begin{array}{l}\text { Unweighted } \\
\text { profile }\end{array}$ & $\begin{array}{l}\text { Weighted } \\
\text { profile }\end{array}$ & $\begin{array}{c}\text { Mean } \\
\text { IGDS score } \\
(95 \% \mathrm{CI})\end{array}$ & $\begin{array}{l}\text { Proportion with } \\
\text { probable IGD } \\
(95 \% \mathrm{CI})\end{array}$ & $\begin{array}{l}\text { Mean } \\
\text { CIUS score } \\
(95 \% \mathrm{CI})\end{array}$ & $\begin{array}{c}\text { Proportion with } \\
\text { probable PIU } \\
(95 \% \mathrm{Cl})\end{array}$ \\
\hline $\begin{array}{l}\text { Total } \\
\text { sample }\end{array}$ & & 51246 & $100 \%$ & $100 \%$ & $0.62(0.61-0.63)$ & $4.1 \%(3.9-4.2)$ & $14.1(14.1-14.1)$ & $7.8 \%(7.6-8.0)$ \\
\hline Age & Gender & & & & & & & \\
\hline \multirow{2}{*}{$<20$} & Male & 59 & $0.1 \%$ & $0.2 \%$ & $1.54(0.99-2.10)$ & $13.6 \%(4.6-22.6)$ & $19.9(17.4-22.4)$ & $15.3 \%(5.8-24.7)$ \\
\hline & Female & 172 & $0.3 \%$ & $0.2 \%$ & $0.97(0.73-1.20)$ & $6.4 \%(2.7-10.1)$ & $21.3(19.7-22.9)$ & $25.0 \%(18.5-31.5)$ \\
\hline \multirow{2}{*}{$20-29$} & Male & 818 & $1.6 \%$ & $4.0 \%$ & $1.85(1.69-2.01)$ & $16.5 \%(14.0-19.1)$ & $19.9(19.2-20.7)$ & $19.4 \%(16.7-22.2)$ \\
\hline & Female & 3,129 & $6.1 \%$ & $3.7 \%$ & $1.04(0.97-1.10)$ & $6.6 \%(5.7-7.5)$ & $19.1(18.8-19.5)$ & $16.0 \%(14.7-17.3)$ \\
\hline \multirow{2}{*}{$30-39$} & Male & 2,762 & $5.4 \%$ & $9.4 \%$ & $1.37(1.29-1.44)$ & $10.3 \%(9.2-11.5)$ & $17.5(17.1-17.9)$ & $13.9 \%(12.6-15.2)$ \\
\hline & Female & 6,657 & $13.0 \%$ & $9.0 \%$ & $0.75(0.72-0.79)$ & $4.3 \%(3.8-4.8)$ & $17.6(17.4-17.9)$ & $12.3 \%(11.5-13.1)$ \\
\hline \multirow{2}{*}{$40-49$} & Male & 7,211 & $14.1 \%$ & $14.5 \%$ & $0.80(0.76-0.84)$ & $6.2 \%(5.7-6.8)$ & $14.8(14.6-15.0)$ & $8.8 \%(8.1-9.4)$ \\
\hline & Female & 7,472 & $14.6 \%$ & $14.2 \%$ & $0.53(0.50-0.56)$ & $2.9 \%(2.5-3.2)$ & $14.7(14.5-14.9)$ & $7.5 \%(6.9-8.1)$ \\
\hline \multirow{2}{*}{$50-59$} & Male & 8,957 & $17.5 \%$ & $14.3 \%$ & $0.41(0.39-0.44)$ & $3.0 \%(2.6-3.3)$ & $12.1(11.9-12.3)$ & $5.2 \%(4.7-5.6)$ \\
\hline & Female & 5,662 & $11.0 \%$ & $14.2 \%$ & $0.39(0.37-0.42)$ & $1.9 \%(1.5-2.2)$ & $12.2(12.0-12.5)$ & $4.2 \%(3.7-4.7)$ \\
\hline \multirow{2}{*}{$60-69$} & Male & 5,519 & $10.8 \%$ & $7.6 \%$ & $0.26(0.23-0.28)$ & $1.4 \%(1.1-1.8)$ & $10.0(9.8-10.3)$ & $2.3 \%(1.9-2.7)$ \\
\hline & Female & 2,470 & $4.8 \%$ & $8.0 \%$ & $0.26(0.22-0.29)$ & $1.3 \%(0.8-1.7)$ & $9.9(9.6-10.2)$ & $2.7 \%(2.0-3.3)$ \\
\hline \multirow[t]{2}{*}{$70>$} & Male & 254 & $0.5 \%$ & $0.3 \%$ & $0.24(0.12-0.36)$ & $2.0 \%(0.2-3.7)$ & $9.2(8.2-10.2)$ & $3.1 \%(1.0-5.3)$ \\
\hline & Female & 104 & $0.2 \%$ & $0.4 \%$ & $0.38(0.14-0.61)$ & $1.9 \%(-0.8-4.6)$ & $9.0(7.4-10.6)$ & $1.9 \%(0-4.6)$ \\
\hline
\end{tabular}


medRxiv preprint doi: https://doi.org/10.1101/2021.03.30.21254614; this version posted March 31, 2021. The copyright holder for this preprint (which was not certified by peer review) is the author/funder, who has granted medRxiv a license to display the preprint in perpetuity.

It is made available under a CC-BY-NC-ND 4.0 International license .

\begin{tabular}{|c|c|c|c|c|c|c|}
\hline & $\begin{array}{l}\text { Sample } \\
\text { size }\end{array}$ & $\begin{array}{c}\text { Unweighted } \\
\text { profile }\end{array}$ & $\begin{array}{l}\text { Mean } \\
\text { IGDS score } \\
(95 \% \mathrm{Cl})\end{array}$ & $\begin{array}{l}\text { Proportion with } \\
\text { probable IGD } \\
(95 \% \mathrm{CI})\end{array}$ & $\begin{array}{l}\text { Mean } \\
\text { CIUS score } \\
(95 \% \mathrm{Cl})\end{array}$ & $\begin{array}{l}\text { Proportion with } \\
\text { probable PIU } \\
(95 \% \mathrm{Cl})\end{array}$ \\
\hline Employment status & 51246 & & & & & \\
\hline Employee & 25041 & $49 \%$ & $0.67(0.65-0.69)$ & $4.8 \%(4.5-5.0)$ & $14.4(14.2-14.5)$ & $8.0 \%(7.6-8.3)$ \\
\hline Executive & 1095 & $2 \%$ & $0.45(0.38-0.53)$ & $2.7 \%(1.8-3.7)$ & $11.1(10.6-11.7)$ & $3.9 \%(2.8-5.1)$ \\
\hline Self-employment/Freelance & 3594 & $7 \%$ & $0.53(0.49-0.58)$ & $3.8 \%(3.2-4.4)$ & $12.5(12.2-12.8)$ & $5.9 \%(5.2-6.7)$ \\
\hline Homemaker & 7731 & $15 \%$ & $0.54(0.51-0.57)$ & $3.0 \%(2.6-3.4)$ & $14.4(14.2-14.6)$ & $7.8 \%(7.2-8.4)$ \\
\hline Part-time job & 8244 & $16 \%$ & $0.58(0.55-0.61)$ & $3.3 \%(2.9-3.7)$ & $14.1(13.9-14.3)$ & $7.0 \%(6.5-7.6)$ \\
\hline Student & 833 & $2 \%$ & $1.26(1.13-1.38)$ & $8.0 \%(6.2-9.9)$ & $21.2(20.5-21.9)$ & $23.5 \%(20.6-26.4)$ \\
\hline Other & 1510 & $3 \%$ & $0.62(0.55-0.70)$ & $4.0 \%(3.0-5.0)$ & $14.1(13.6-14.6)$ & $9.1 \%(7.7-10.6)$ \\
\hline No employee & 3198 & $6 \%$ & $0.50(0.46-0.54)$ & $2.8 \%(2.3-3.4)$ & $12.8(12.5-13.2)$ & $7.5 \%(6.6-8.5)$ \\
\hline \multicolumn{7}{|l|}{ Existence of child(ren) } \\
\hline No children & 21508 & $42 \%$ & $0.71(0.69-0.73)$ & $4.5 \%(4.2-4.8)$ & $15.4(15.2-15.5)$ & $9.9 \%(9.5-10.3)$ \\
\hline Have child(ren) & 29738 & & $0.55(0.54-0.57)$ & $3.8 \%(3.5-4.0)$ & $13.2(13.1-13.4)$ & $6.3 \%(6.1-6.6)$ \\
\hline \multicolumn{7}{|l|}{ Marital status } \\
\hline Not married & 17664 & $34 \%$ & $0.72(0.69-0.74)$ & $4.5 \%(4.2-4.8)$ & $15.5(15.4-15.7)$ & $10.3 \%(9.9-10.8)$ \\
\hline Married & 33582 & $66 \%$ & $0.57(0.55-0.58)$ & $3.8 \%(3.6-4.0)$ & $13.4(13.3-13.5)$ & $6.5 \%(6.2-6.8)$ \\
\hline \multicolumn{7}{|l|}{ Household income, \$ } \\
\hline$\sim 39999$ & 11962 & $23 \%$ & $0.65(0.62-0.68)$ & $4.1 \%(3.8-4.5)$ & $14.3(14.1-14.5)$ & $8.5 \%(8.0-9.0)$ \\
\hline $40000 \sim 80000$ & 17872 & $35 \%$ & $0.61(0.59-0.63)$ & $4.0 \%(3.8-4.3)$ & $14.2(14.0-14.3)$ & $7.7 \%(7.3-8.1)$ \\
\hline $80000 \sim 120000$ & 4687 & $9 \%$ & $0.62(0.58-0.67)$ & $4.9 \%(4.3-5.5)$ & $13.6(13.3-13.9)$ & $7.0 \%(6.3-7.8)$ \\
\hline$\sim 120000$ & 4508 & $9 \%$ & $0.63(0.58-0.68)$ & $4.7 \%(4.1-5.3)$ & $13.2(12.9-13.5)$ & $6.8 \%(6.1-7.5)$ \\
\hline Missing & 12217 & $24 \%$ & $0.59(0.57-0.62)$ & $3.5 \%(3.1-3.8)$ & $14.4(14.2-14.6)$ & $8.1 \%(7.6-8.6)$ \\
\hline \multicolumn{7}{|l|}{ Living with someone or alone } \\
\hline Living with someone & 43249 & $84 \%$ & $0.61(0.60-0.62)$ & $4.0 \%(3.8-4.2)$ & $14.1(14.0-14.2)$ & $7.5 \%(7.3-7.8)$ \\
\hline Alone & 7997 & $16 \%$ & $0.66(0.62-0.69)$ & $4.3 \%(3.9-4.8)$ & $14.6(14.3-14.8)$ & $9.4 \%(8.7-10.0)$ \\
\hline \multicolumn{7}{|l|}{ About COVID-19 infected } \\
\hline Thinking negative themselves & 44360 & $87 \%$ & $0.56(0.54-0.57)$ & $3.4 \%(3.2-3.5)$ & $14.1(14.0-14.2)$ & $7.6 \%(7.3-7.8)$ \\
\hline Received a diagnosis & 270 & $1 \%$ & $3.38(3.03-3.73)$ & $39.3 \%(33.4-45.1)$ & $20.6(19.4-21.8)$ & $19.6 \%(14.9-24.4)$ \\
\hline Thinking positive themselves & 1136 & $2 \%$ & $1.41(1.28-1.54)$ & $12.5 \%(10.6-14.4)$ & $18.7(18.0-19.3)$ & $15.6 \%(13.5-17.7)$ \\
\hline Missing & 5480 & $11 \%$ & $0.81(0.77-0.86)$ & $6.1 \%(5.5-6.8)$ & $13.41(13.1-13.7)$ & $7.8 \%(7.1-8.5)$ \\
\hline
\end{tabular}

Sample sizes are unweighted. Concerning gender and age subgroups, we used the weighted profile as representative of the Japanese population.

IGDS: Internet gaming disorder scale, CIUS: Compulsive internet use scale.

IGDS scores $\geq 5$ indicate a clinically probable level of IGD. CIUS scores $\geq 29$ indicate a clinically probable level of IGD.

\section{Changes of each IGD item between before and during the pandemic}

Seven out of nine IGD symptoms increased significantly during the pandemic (Figure 2). Especially, 'Tolerance', 'Withdrawal', 'Persistence' and 'Displacement' were greatly exacerbated during the pandemic (Tolerance: $t_{3937}=4.60, p<.001$; Withdrawal: $t_{3937}=4.44, p<.001$;

Persistence: $t_{3937}=5.40, p<.001$; Displacement: $\left.t_{3937}=5.94, p<.001\right)$. 


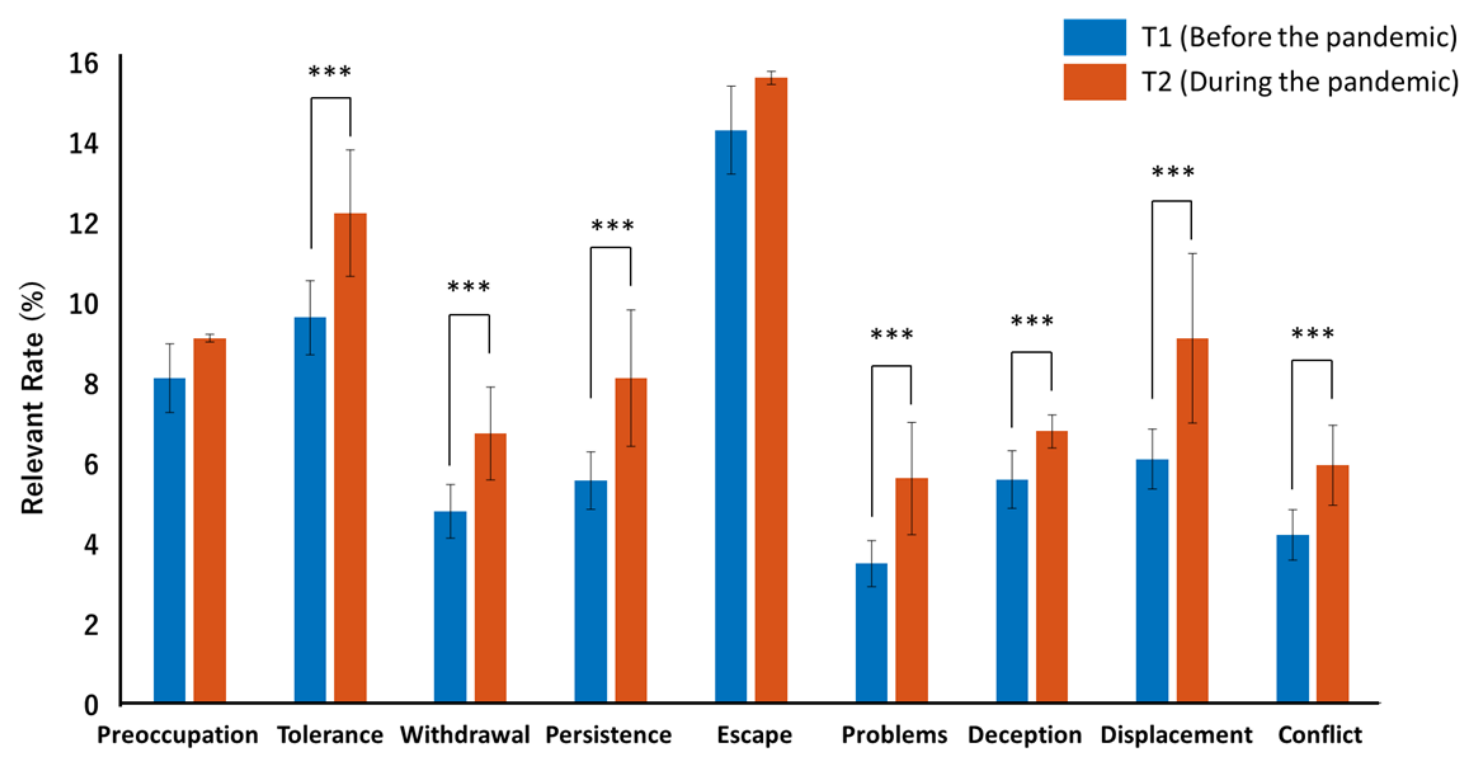

Figure 2. Comparison of IGD symptoms before and during the pandemic in the study population. These 9 symptoms are defined in DSM-5(American Psychiatric Association, 2013). ${ }^{* * *} p \leq 0.001$

\section{Multiple logistic regression analyses}

Multiple logistic regression analyses were used to examine the effects of demographic factors on development of probable IGD and PIU (Table 2). The odds ratio (OR) for probable IGD development in males was $2.21(95 \% \mathrm{Cl}$ [1.42 to 3.42$])$, whereas the OR among young people $(<30)$ relative to people 40 to 49 years was $2.10(95 \% \mathrm{Cl}[1.18$ to 3.75$])$. The OR in those who decreased face-to-face communication-time with family was $1.71(95 \% \mathrm{Cl}$ [1.15 to 2.53$])$ relative to those who reported no change in communication time. Also, the OR among those who decreased online communication time with family was $1.52(95 \% \mathrm{Cl}$ [1.04 to 2.24]). The OR of those suffering COVID-19 infections was 5.67 (95\% $\mathrm{Cl}$ [1.33 to 24.16]) relative to those without COVID-19 infections.

The OR of people 30-39 years for probable PIU development relative to those aged 
medRxiv preprint doi: https://doi.org/10.1101/2021.03.30.21254614; this version posted March 31, 2021. The copyright holder for this preprint (which was not certified by peer review) is the author/funder, who has granted medRxiv a license to display the preprint in perpetuity. It is made available under a CC-BY-NC-ND 4.0 International license.

between 40 and 49 was $1.50(95 \% \mathrm{Cl}$ [1.09 to 2.07]). That of people who increased face-to-facecommunication time with their families relative to those who reported no change was 1.38 $(95 \% \mathrm{Cl}[1.03$ to 1.84$])$. In regard to smartphone use, the OR of people who reported increases in their weekday smartphone use relative to that of those who reported no change was 1.46 (95\% Cl [1.05 to 2.02]). The OR of people who reported increased weekend smartphone use was $1.51(95 \% \mathrm{Cl}$ [1.07 to 2.12$])$ while that of people who reported a decrease was $1.49(95 \% \mathrm{Cl}$ [1.00 to 2.21]). 
medRxiv preprint doi: https://doi.org/10.1101/2021.03.30.21254614; this version posted March 31, 2021. The copyright holder for this preprint (which was not certified by peer review) is the author/funder, who has granted medRxiv a license to display the preprint in perpetuity.

It is made available under a CC-BY-NC-ND 4.0 International license .

Table 2. Results of logistic regression analysis predicting exacerbation of probable IGD and PIU (probable IGD development, N=3793; probable PIU development, N=3626).

\begin{tabular}{|c|c|c|c|c|c|c|}
\hline \multirow[b]{2}{*}{ Resource } & \multicolumn{3}{|c|}{ Probable IGD by Resources } & \multicolumn{3}{|c|}{ Probable PIU by Resources } \\
\hline & $\begin{array}{l}\text { Sample } \\
\text { size }\end{array}$ & OR $(95 \% \mathrm{Cl})$ & $p$ value & $\begin{array}{c}\text { Sample } \\
\text { size }\end{array}$ & OR $(95 \% \mathrm{Cl})$ & $p$ value \\
\hline \multicolumn{7}{|l|}{ Gender } \\
\hline Female & 1,811 & 1 [Reference] & NA & 1,702 & 1 [Reference] & NA \\
\hline Male & 1,982 & $2.21(1.42-3.42)$ & .000 & 1,924 & $1.38(1.01-1.89)$ & .043 \\
\hline \multicolumn{7}{|l|}{ Marital status } \\
\hline Not married & 1,336 & 1 [Reference] & NA & 1,258 & 1 [Reference] & NA \\
\hline Married & 2,457 & $1.68(1.00-2.84)$ & .051 & 2,368 & $0.83(0.56-1.22)$ & 338 \\
\hline \multicolumn{7}{|l|}{ Existence of child(ren) } \\
\hline No children & 1,551 & 1 [Reference] & NA & 1,464 & 1 [Reference] & NA \\
\hline Have child(ren) & 2,242 & $0.65(0.42-1.00)$ & .051 & 2,162 & $1.22(0.87-1.71)$ & .256 \\
\hline \multicolumn{7}{|l|}{ Living with someone or alone } \\
\hline Living with someone & 3,166 & 1 [Reference] & NA & 3,030 & 1 [Reference] & NA \\
\hline Alone & 627 & $0.92(0.52-1.60)$ & .757 & 596 & $1.12(0.75-1.68)$ & .581 \\
\hline \multicolumn{7}{|l|}{ Age } \\
\hline $20-29$ & 287 & $2.10(1.18-3.75)$ & .012 & 279 & $1.25(0.77-2.03)$ & .365 \\
\hline $30-39$ & 725 & $1.34(0.86-2.09)$ & .189 & 690 & $1.50(1.09-2.07)$ & .014 \\
\hline $40-49$ & 1,095 & 1 [Reference] & NA & 1,053 & NA & NA \\
\hline $50-59$ & 1,091 & $0.55(0.34-0.89)$ & .015 & 1,035 & $0.68(0.49-0.96)$ & .029 \\
\hline $60-$ & 595 & $0.32(0.15-0.69)$ & .004 & 569 & $0.36(0.21-0.61)$ & .000 \\
\hline \multicolumn{7}{|l|}{ Household income (\$) } \\
\hline 〜9999 & 942 & 1 [Reference] & NA & 877 & 1 [Reference] & NA \\
\hline $40000 \sim 80000$ & 1,482 & $1.20(0.75-1.94)$ & .446 & 1,422 & $1.04(0.73-1.48)$ & .828 \\
\hline $80000 \sim 120000$ & 341 & $1.26(0.65-2.44)$ & .495 & 332 & $1.18(0.72-1.95)$ & .513 \\
\hline Missing & 310 & $1.11(0.55-2.26)$ & .766 & 304 & $1.67(1.03-2.70)$ & .037 \\
\hline$\sim 120000$ & 718 & $0.83(0.47-1.47)$ & .525 & 691 & $0.98(0.66-1.46)$ & .929 \\
\hline \multicolumn{7}{|l|}{ Employment status } \\
\hline Employee & 1,928 & 1 [Reference] & NA & 1,855 & 1 [Reference] & NA \\
\hline Executive & 71 & $0.31(0.04-2.30)$ & .250 & 69 & $0.40(0.10-1.69)$ & .214 \\
\hline Self-employment/Freelance & 272 & $0.64(0.29-1.43)$ & .281 & 271 & $0.97(0.57-1.64)$ & .908 \\
\hline Homemaker & 593 & $0.66(0.31-1.38)$ & .271 & 551 & $1.34(0.86-2.10)$ & .194 \\
\hline Part-time job & 576 & $1.05(0.59-1.88)$ & .858 & 552 & $1.08(0.72-1.64)$ & .706 \\
\hline Student & 37 & $1.65(0.54-5.02)$ & .375 & 36 & $0.71(0.20-2.54)$ & .603 \\
\hline Other & 94 & $1.19(0.41-3.45)$ & .754 & 89 & $2.38(1.25-4.52)$ & . 008 \\
\hline No employee & 222 & $1.02(0.41-2.56)$ & .968 & 203 & $1.17(0.61-2.26)$ & .635 \\
\hline \multicolumn{7}{|l|}{ About COVID-19 infected } \\
\hline Thinking negative themselves & 3,528 & 1 [Reference] & NA & 3,371 & NA & NA \\
\hline Received a diagnosis & 13 & $5.67(1.33-24.16)$ & .019 & 15 & $2.94(0.79-10.95)$ & .108 \\
\hline Thinking positive themselves & 80 & $3.95(1.98-7.89)$ & .000 & 74 & $1.69(0.82-3.49)$ & .155 \\
\hline Missing & 172 & $2.38(1.32-4.28)$ & .004 & 166 & $2.62(1.69-4.06)$ & .000 \\
\hline \multicolumn{7}{|c|}{$\begin{array}{l}\text { Face communication time difference } \\
\text { (T2-TI) }\end{array}$} \\
\hline No change & 2,051 & 1 [Reference] & NA & 1,957 & 1 [Reference] & NA \\
\hline Increased & 899 & $1.26(0.83-1.93)$ & .281 & 875 & $1.38(1.03-1.84)$ & .032 \\
\hline Decreased & 843 & $1.71(1.15-2.53)$ & .008 & 794 & $1.03(0.75-1.43)$ & .842 \\
\hline \multicolumn{7}{|c|}{$\begin{array}{l}\text { Online communication time difference } \\
\text { (T2-TI) }\end{array}$} \\
\hline No change & 2,186 & 1 [Reference] & NA & 2,080 & 1 [Reference] & NA \\
\hline Increased & 677 & $1.39(0.89-2.16)$ & .144 & 660 & $1.30(0.95-1.78)$ & .102 \\
\hline Decreased & 930 & $1.52(1.04-2.24)$ & .033 & 886 & $1.05(0.77-1.43)$ & .742 \\
\hline \multicolumn{7}{|c|}{$\begin{array}{l}\text { Time difference spent using smartphones } \\
\text { on weekdays }(T 2-T 1)\end{array}$} \\
\hline No change & 1,754 & 1 [Reference] & NA & 1,698 & 1 [Reference] & NA \\
\hline Increased & 1194 & $1.14(0.73-1.76)$ & .567 & 1141 & $1.46(1.05-2.02)$ & .024 \\
\hline Decreased & 845 & $1.06(0.64-1.76)$ & .806 & 787 & $0.96(0.64-1.42)$ & .822 \\
\hline \multicolumn{7}{|c|}{$\begin{array}{l}\text { Time difference spent using smartphones } \\
\text { on weekends (T2-TI) }\end{array}$} \\
\hline No change & 1,526 & 1 [Reference] & NA & 1,473 & 1 [Reference] & NA \\
\hline Increased & 1,388 & $1.30(0.83-2.03)$ & .252 & 1,317 & $1.51(1.07-2.12)$ & .018 \\
\hline Decreased & 879 & $1.32(0.79-2.20)$ & .292 & 836 & $1.49(1.00-2.21)$ & .049 \\
\hline
\end{tabular}


medRxiv preprint doi: https://doi.org/10.1101/2021.03.30.21254614; this version posted March 31, 2021. The copyright holder for this preprint (which was not certified by peer review) is the author/funder, who has granted medRxiv a license to display the preprint in perpetuity.

It is made available under a CC-BY-NC-ND 4.0 International license .

\section{Discussion}

This is the first online survey to assess changes in prevalence of probable Internet gaming disorder (IGD) and problematic internet use (PIU) during the COVID-19 pandemic in Japan. Probable IGD prevalence was $4.1 \%$ during the pandemic in the survey population $(\mathrm{N}=$ $51,246)$. Analyses revealed that probable IGD prevalence increased more than 1.6 times (from $3.7 \%$ to $5.9 \%$ ) during the pandemic. Probable IGD prevalence during the pandemic was higher than reported (1 - 2.5\% (Pontes et al., 2016; Przybylski et al., 2017; Wu et al., 2018)) before the pandemic. Probable PIU prevalence was $7.8 \%$ during the pandemic in the survey population (N $=51,246)$ (Figure 1). Analyses of the study population $(\mathrm{N}=3,938)$ revealed that probable PIU prevalence increased more than 1.5 times during (from $7.9 \%$ to $11.6 \%$ ) the pandemic. Probable PIU prevalence was also higher than reported in studies before the pandemic (3.2 - 3.7\% (Kuss et al., 2013a, 2013b)). Prevalence of probable IGD among younger people (<30 years old) was $8.6 \%$ in the survey population, higher than reported in studies among children and adolescents (1.2 - 7.5\% (Jeong et al., 2020; Rehbein et al., 2015; Taechoyotin et al., 2020; Wartberg et al., 2020)) before the pandemic. It increased more than 1.8 times (from $7.7 \%$ to $13.8 \%$ ) during the pandemic.

All symptoms of IGD increased during the pandemic. 'Tolerance', 'Withdrawal' and 'Displacement' were especially exacerbated. Rehbein (Rehbein et al., 2015) reported that symptoms related to 'Tolerance', 'Withdrawal', and 'Displacement' are the core symptoms of IGD. Moreover, these symptoms interfere with abstinence from gaming behavior (King et al., 2018), which prolongs the IGD state. Thus, the greater number of individuals with IGD is likely not just a transitory problem during the COVID-19 pandemic.

We also found that younger people $(<30)$ were at 2.1 times greater risk of IGD than the more mature group (40-49 years). This suggests that young people are more vulnerable to Internet-gaming-related problems. Decreased face-to-face and online communication time with family members were also associated with a higher risk of exacerbated IGD during the 
medRxiv preprint doi: https://doi.org/10.1101/2021.03.30.21254614; this version posted March 31, 2021. The copyright holder for this preprint (which was not certified by peer review) is the author/funder, who has granted medRxiv a license to display the preprint in perpetuity.

It is made available under a CC-BY-NC-ND 4.0 International license .

pandemic relative to persons whose screen time did not change (1.71 times and 1.52 times, respectively). These may suggest that loneliness or boredom due to decreasing time with family drove people to play games and become addicted. Additionally, we found that individuals infected with COVID-19 were at 5.67 times greater risk of progression in IGD than uninfected individuals. This suggests that stress and lifestyle changes caused by COVID-19 infection exacerbate IGD remarkably. Infected individuals reported an increase in IGD, possibly because they used the internet or games to avoid or cope with stress associated with the infection (Fazeli et al., 2020; Lee et al., 2017).

Increased smartphone use both on weekdays and weekends was associated with a greater risk of PIU development (weekdays: 1.46 times, weekends 1.51 times). Data from the Japanese Ministry of Internal Affairs and Communications shows increases in smartphone use on weekdays and weekends under states of emergency ("Information and Communications in Japan., 2020"). A previous study showed increases in smartphone use due to the pandemic (Chen et al., 2021). Our results may reflect forgoing non-essential and non-urgent activities due to the pandemic. On the other hand, those who decreased their smartphone use time on weekends still showed 1.49 times more PIU. This may reflect a shift from smartphone use away from home to use of personal computers or tablet computers at home. Therefore, simply monitoring smartphone use is not sufficient for early detection of PIU. Instead, we need to monitor screen time regardless of the device. People who increased face-to-face communication time with family were still at 1.38 times higher risk of PIU development relative to people with no change. This result is inconsistent with a previous study that reported face-toface communication may protect against Internet-related behavior problems (Kim et al., 2015). Further studies are required to further illuminate the underlying basis for this inconsistency, such as differences in culture or momentum of the pandemic.

As shown above, most of the risks are common to both IGD and PIU, but some factors seem to have different effects on those risks. For example, a decrease in face-to-face 
medRxiv preprint doi: https://doi.org/10.1101/2021.03.30.21254614; this version posted March 31, 2021. The copyright holder for this preprint (which was not certified by peer review) is the author/funder, who has granted medRxiv a license to display the preprint in perpetuity.

It is made available under a CC-BY-NC-ND 4.0 International license .

communication time with family was a significant risk factor of IGD. In contrast, an increase in face-to-face communication time with family was a significant risk factor for PIU. Thus, approaches for early detection and prevention of internet-addictive behavior may differ in each group. This should be examined in future research.

There are several limitations to this study. First, this is a survey using an online recruiting method, and there may be some sampling bias. The study population $(\mathrm{N}=3,938)$ was extracted from the survey population $(\mathrm{N}=51,246)$ such that the study population includes equal numbers of individuals in each quintile relative to the problematic smartphone use score. However, Pearson correlations of the prevalence of probable IGD and probable PIU in each age and sex group between the survey population and the study population were significant $(r=0.94, p$ $<.001, r=0.90, p<.001)$. This shows the reliability of probable IGD and probable PIU as ratio scales, even if the raw value was overestimated. Second, this survey was taken in Japan. Instead of locking down the city, the Japanese government declared a state of emergency to control the spread of the COVID-19 pandemic. People were encouraged, but not forced to stay home. Therefore, it is unclear whether the results of this Japanese study apply equally to other countries, especially those that locked down to control the pandemic. It is important to compare these results with data from other countries having different ethnicities and government strategies. Despite these limitations, this study shows increasing IGD and PIU and identifies atrisk populations for internet-related problems.

\section{Conclusion}

In summary, the prevalence of IGD and the prevalence of PIU have increased 1.6 and 1.5 times during the COVID-19 pandemic, respectively. Young people and those infected with COVID-19 are at greater risk for IGD. The pandemic has seriously changed people's lives, and some of the changes induce problematic internet-related behaviors. It is essential to mitigate such impacts of the COVID-19 pandemic to promote healthier societies. 
medRxiv preprint doi: https://doi.org/10.1101/2021.03.30.21254614; this version posted March 31, 2021. The copyright holder for this preprint (which was not certified by peer review) is the author/funder, who has granted medRxiv a license to display the preprint in perpetuity.

It is made available under a CC-BY-NC-ND 4.0 International license .

Acknowledgments: This research was supported by a KDDI collaborative research contract. It was also supported by Innovative Science and Technology Initiative for Security Grant Number JPJ004596, ATLA, Japan. We thank Rumi Yorizawa, Misa Murakami, Chika Hosomi, and Miho Nagata for data collection and organization. We also thank Aurelio Cortese for helpful discussion.

\section{References}

American Psychiatric Association, 2013. Diagnostic and Statistical Manual of Mental Disorders (DSM-5®). American Psychiatric Pub.

Bonny-Noach, H., Gold, D., 2020. Addictive behaviors and craving during the COVID-19 pandemic of people who have recovered from substance use disorder. J. Addict. Dis. 1-20. Chen, I.-H., Chen, C.-Y., Pakpour, A.H., Griffiths, M.D., Lin, C.-Y., 2020. Internet-Related Behaviors and Psychological Distress Among Schoolchildren During COVID-19 School Suspension. J. Am. Acad. Child Adolesc. Psychiatry 59, 1099-1102.e1.

Chen, I.-H., Chen, C.-Y., Pakpour, A.H., Griffiths, M.D., Lin, C.-Y., Li, X.-D., Tsang, H.W.H., 2021. Problematic internet-related behaviors mediate the associations between levels of internet engagement and distress among schoolchildren during COVID-19 lockdown: A longitudinal structural equation modeling study. J Behav Addict. https://doi.org/10.1556/2006.2021.00006

Chiba, T., Oka, T., Hamamura, T., Kobayashi, N., Honjo, M., Miyake, Y., Kubo, T., Toda, H., Hishimoto, A., Boku, S., Others, 2020. PTSD symptoms related to COVID-19 as a high risk factor for suicide-Key to prevention. medRxiv.

Fazeli, S., Mohammadi Zeidi, I., Lin, C.-Y., Namdar, P., Griffiths, M.D., Kwasi Ahorsu, D., Pakpour, A., 2020. Depression, anxiety, and stress mediate the associations between internet gaming disorder, insomnia, and quality of life during the COVID-19 outbreak. 
medRxiv preprint doi: https://doi.org/10.1101/2021.03.30.21254614; this version posted March 31, 2021. The copyright holder for this preprint (which was not certified by peer review) is the author/funder, who has granted medRxiv a license to display the preprint in perpetuity. It is made available under a CC-BY-NC-ND 4.0 International license .

Addictive Behaviors Reports 100307.

Holmes, E.A., O’Connor, R.C., Perry, V.H., Tracey, I., 2020. Multidisciplinary research priorities for the COVID-19 pandemic: a call for action for mental health science. Lancet Psychiatry. Jeong, H., Yim, H.W., Lee, S.-Y., Lee, H.K., Potenza, M.N., Lee, H., 2020. Factors associated with severity, incidence, or persistence of internet gaming disorder in children and adolescents: a two-year longitudinal study. Addiction. https://doi.org/10.1111/add.15366 Jeromin, F., Rief, W., Barke, A., 2016. Using two web-based addiction Stroops to measure the attentional bias in adults with Internet Gaming Disorder. J Behav Addict 5, 666-673.

Kato, T.A., Shinfuku, N., Tateno, M., 2020. Internet society, internet addiction, and pathological social withdrawal: the chicken and egg dilemma for internet addiction and hikikomori. Curr. Opin. Psychiatry 33, 264-270.

Kim, J.-H., Seo, M., David, P., 2015. Alleviating depression only to become problematic mobile phone users: Can face-to-face communication be the antidote? Comput. Human Behav. 51, 440-447.

King, D.L., Adair, C., Saunders, J.B., Delfabbro, P.H., 2018. Clinical predictors of gaming abstinence in help-seeking adult problematic gamers. Psychiatry Res. 261, 581-588.

King, D.L., Delfabbro, P.H., Billieux, J., Potenza, M.N., 2020. Problematic online gaming and the COVID-19 pandemic. J Behav Addict 9, 184-186.

Ko, C.-H., Yen, J.-Y., 2020. Impact of COVID-19 on gaming disorder: Monitoring and prevention. J Behav Addict 9, 187-189.

Kuss, D.J., Griffiths, M.D., Binder, J.F., 2013a. Internet addiction in students: Prevalence and risk factors. Comput. Human Behav. 29, 959-966.

Kuss, D.J., van Rooij, A.J., Shorter, G.W., Griffiths, M.D., van de Mheen, D., 2013b. Internet addiction in adolescents: Prevalence and risk factors. Comput. Human Behav. 29, 19871996.

Lee, J.-Y., Kim, S.-W., Kang, H.-J., Kim, S.-Y., Bae, K.-Y., Kim, J.-M., Shin, I.-S., Yoon, J.-S., 
medRxiv preprint doi: https://doi.org/10.1101/2021.03.30.21254614; this version posted March 31, 2021. The copyright holder for this preprint (which was not certified by peer review) is the author/funder, who has granted medRxiv a license to display the preprint in perpetuity. It is made available under a CC-BY-NC-ND 4.0 International license .

2017. Relationship between Problematic Internet Use and Post-Traumatic Stress Disorder Symptoms among Students Following the Sewol Ferry Disaster in South Korea. Psychiatry Investig. 14, 871-875.

Lemmens, J.S., Valkenburg, P.M., Gentile, D.A., 2015. The Internet Gaming Disorder Scale. Psychol. Assess. 27, 567-582.

McGinty, E.E., Presskreischer, R., Han, H., Barry, C.L., 2020. Psychological distress and loneliness reported by US adults in 2018 and April 2020. JAMA 324, 93-94.

Meerkerk, G.-J., Van Den Eijnden, R.J.J.M., Vermulst, A.A., Garretsen, H.F.L., 2009. The Compulsive Internet Use Scale (CIUS): some psychometric properties. Cyberpsychol. Behav. 12, 1-6.

Ministry of Internal Affairs and Communications, Japan ,2020. Information and Communications in Japan 2020 https://www.soumu.go.jp/johotsusintokei/whitepaper/eng/WP2020/2020index.html (accessed 2.26.21).

Panno, A., Carbone, G.A., Massullo, C., Farina, B., Imperatori, C., 2020. COVID-19 Related Distress Is Associated With Alcohol Problems, Social Media and Food Addiction Symptoms: Insights From the Italian Experience During the Lockdown. Front. Psychiatry $11,1314$.

Pontes, H.M., Macur, M., Griffiths, M.D., 2016. Internet Gaming Disorder Among Slovenian Primary Schoolchildren: Findings From a Nationally Representative Sample of Adolescents. J Behav Addict 5, 304-310.

Przybylski, A.K., Weinstein, N., Murayama, K., 2017. Internet Gaming Disorder: Investigating the Clinical Relevance of a New Phenomenon. Am. J. Psychiatry 174, 230-236.

Rehbein, F., Kliem, S., Baier, D., Mößle, T., Petry, N.M., 2015. Prevalence of internet gaming disorder in German adolescents: Diagnostic contribution of the nine DSM-5 criteria in a state-wide representative sample. Addiction 110, 842-851.

Schmidt, S.C.E., Anedda, B., Burchartz, A., Eichsteller, A., Kolb, S., Nigg, C., Niessner, C., 
medRxiv preprint doi: https://doi.org/10.1101/2021.03.30.21254614; this version posted March 31, 2021. The copyright holder for this preprint (which was not certified by peer review) is the author/funder, who has granted medRxiv a license to display the preprint in perpetuity. It is made available under a CC-BY-NC-ND 4.0 International license .

Oriwol, D., Worth, A., Woll, A., 2020. Physical activity and screen time of children and adolescents before and during the COVID-19 lockdown in Germany: a natural experiment. Sci. Rep. 10, 21780.

Shen, Y., Meng, F., Xu, H., Li, X., Zhang, Y., Huang, C., Luo, X., Zhang, X.Y., 2020. Internet addiction among college students in a Chinese population: Prevalence, correlates, and its relationship with suicide attempts. Depress. Anxiety 37, 812-821.

Sun, Y., Li, Y., Bao, Y., Meng, S., Sun, Y., Schumann, G., Kosten, T., Strang, J., Lu, L., Shi, J., 2020. Brief report: increased addictive internet and substance use behavior during the COVID-19 pandemic in China. Am. J. Addict. 29, 268-270.

Taechoyotin, P., Tongrod, P., Thaweerungruangkul, T., Towattananon, N., Teekapakvisit, P., Aksornpusitpong, C., Sathapornpunya, W., Hempatawee, N., Rangsin, R., Mungthin, M., Piyaraj, P., 2020. Prevalence and associated factors of internet gaming disorder among secondary school students in rural community, Thailand: a cross-sectional study. BMC Res. Notes 13, 11.

Tsumura, H., Kanda, H., Sugaya, N., Tsuboi, S., Takahashi, K., 2018. Prevalence and Risk Factors of Internet Addiction Among Employed Adults in Japan. J. Epidemiol. 28, 202-206. Wartberg, L., Kriston, L., Thomasius, R., 2020. Internet gaming disorder and problematic social media use in a representative sample of German adolescents: Prevalence estimates, comorbid depressive symptoms and related psychosocial aspects. Comput. Human Behav. 103, 31-36.

Wong, H.Y., Mo, H.Y., Potenza, M.N., Chan, M.N.M., Lau, W.M., Chui, T.K., Pakpour, A.H., Lin, C.-Y., 2020. Relationships between Severity of Internet Gaming Disorder, Severity of Problematic Social Media Use, Sleep Quality and Psychological Distress. Int. J. Environ. Res. Public Health 17. https://doi.org/10.3390/ijerph17061879

Wu, A.M.S., Chen, J.H., Tong, K.-K., Yu, S., Lau, J.T.F., 2018. Prevalence and associated factors of Internet gaming disorder among community dwelling adults in Macao, China. $\mathrm{J}$ 
medRxiv preprint doi: https://doi.org/10.1101/2021.03.30.21254614; this version posted March 31, 2021. The copyright holder for this preprint (which was not certified by peer review) is the author/funder, who has granted medRxiv a license to display the preprint in perpetuity. It is made available under a CC-BY-NC-ND 4.0 International license.

Behav Addict 7, 62-69.

World Health Organization, 2020. Excessive screen use and gaming considerations during COVID19. 